\title{
An Innovative Approach for Gob-Side Entry Retaining With Thick and Hard Roof: A Case Study
}

\author{
Zizheng ZHANG, Weijun WANG, Shuqing LI, Jianbiao BAI, Shengpeng HAO, Hai WU, Xianyang YU
}

\begin{abstract}
An innovative roadway layout in a Chinese colliery based on gob-side entry retaining (GER) with thick and hard roof (THR) was introduced. Suspended roof is left with a large area in GER with THR, which leads to large area roof weighting (LARW). LARW for GER with THR and mechanism of shallow-hole blasting to force roof caving in GER were expounded. Key parameters of shallow-hole blasting to force roof caving are proposed. LS-DYNA3D was used to validate the rationality of those key parameters, and UDEC was used to discuss and validate shallow-hole blasting to force roof-caving effect by contrast to the model without blasting and the model with shallow-hole blasting. Moreover, shallow-hole blasting technology to force roof caving for GER with THR was carried out in the Chinese colliery as a case study. Field test indicates that shallow-hole blasting technology effectively controls ground deformation of GER with THR and prevents LARW.
\end{abstract}

Keywords: gob-side entry retaining; large area roof weighting; LS-DYNA3D; shallow-hole blasting; thick and hard roof

\section{INTRODUCTION}

In the past few decades, longwall mining has been widely employed in Chinese coal mines. Meanwhile, gobside entry retaining (GER) was carried out to improve coal recovery rate, provide site for gas control or water drainage, and to achieve longwall mining without coal pillar [1]. Hence, vast achievements about GER have been made in China so far, which include the application of GER in thin (height $<1.3 \mathrm{~m}$ ) [2], medium-thick coal seam (height from $1.3 \mathrm{~m}$ to $3.5 \mathrm{~m}$ ) [3, 4] and some thick coal seam (height $>3.5 \mathrm{~m}$ ) with medium-stiffness roof [5-7]. Roadside support body is made up of high water material, concrete, gangue and other backfill material [8-11]. For GER with thick and hard roof (THR), suspended roof is left with a large area and a long duration; therefore, the roadside support body tends to great deformation and instability under abutment stress, and more serious accidents such as large area roof weighting (LARW) and wind blast damage particularly [12-14]. The phenomenon mentioned above brings a serious threat to safe mining, thus some necessary and effective measures should be taken to prevent these disasters.

Now the common measure is to change mechanical environment for GER, weaken roof rock mass strength, and optimize roof fracture structure. Main technologies are deep-hole and shallow-hole blasting, water injection for softening rock mass, hydraulic fracture to weaken rock mass, decorating unloading groove or pressure relief hole, and other technologies which can transfer stress. Many projects show that deep-hole blasting technology is a frequent way to relief roof pressure [15-17]. At present, the deep-hole pre-splitting blasting to relief roof pressure is undertaken in the roadways or in the panel, and blasting parameters are mostly accepted by adopting numerical and laboratory physical experiments. The shallow-hole blasting technology is taken behind hydraulic supports less than the deep-hole pre-splitting blasting. However, so far, deep-hole pre-splitting blasting technology to control roof caving is always taken in GER or in the panel and concerned blasting parameters are mostly adopted by numerical calculation and laboratory physical experiments. However, shallow-hole blasting technology for GER with
THR is taken less. Mechanism of shallow-hole blasting technology for GER with THR remains to be researched systematically. Hence, the authors attempt to propose a new approach for GER with THR based on the field test and numerical simulation. Taking the practice for GER with THR in Xinchao Colliery, Shanxi Province of China as the engineering background, theoretical analysis and numerical simulation are integratedly adopted to study and uncover the shallow-hole blasting mechanism for GER with THR. Research results would help to carry out the file test for GER with THR successfully and ensure safe mining.

\section{DESCRIPTION OF CASE STUDY SITE \\ 2.1 Mining and Geological Conditions}

The present analysis was based on the mining conditions of the panel 90101 in Xinchao Colliery, located north of the Qinshui coalfield in Shanxi Province of China. The 90101 panel has a width of $180 \mathrm{~m}$ and a length of 830 $\mathrm{m}$, the $9+10$ \# Coal Seam is the mined seam with the dip angle of $10^{\circ}$, which has a total thickness of $3.0 \mathrm{~m}$ and is stuffed with a thickness of $0.2 \mathrm{~m}$ gange. The 90101 panel is the first panel of Xinchao Colliery, without any mining around, and develops by the two-entry system with both entries $3.0 \mathrm{~m}$ high by $4.2 \mathrm{~m}$ wide excavated along the seam floor (Fig. 1a). The stratigraphic column of the 9+10\# Coal Seam is shown in Fig. 1b.

\subsection{Roof Weighting Analysis}

The mined-out coal seam of the 90101 panel is shallow, thus the immediate roof structure can be simplified to a clamped beam before the first weighting without controlled caving, and the immediate roof structure can be simplified to a simply supported beam during period weighting. According to the elasticity mechanics theory and the maximum tensile strength criterion, the immediate roof structure breaks firstly in the middle of the beam, the limit safe length of the immediate roof rock beam can be calculated by the following equations [18], respectively: 


$$
\begin{aligned}
& L_{\mathrm{S}}=h \sqrt{\frac{2 \sigma_{\mathrm{t}}}{q}} \\
& L=2 h \sqrt{\frac{\sigma_{\mathrm{t}}}{3 q}}
\end{aligned}
$$

where $L_{\mathrm{S}}$ is rock beam's limit safe length in the conditions of both ends clamped or the first roof weighting length, $\mathrm{m}$; $L$ is rock beam's limit safe length in the conditions of both ends simply supported or the periodic roof weighting length, $\mathrm{m}$; $h$ is the immediate roof's thickness, $3.0 \mathrm{~m}$; $\sigma_{\mathrm{t}}$ is the roof stratum's tensile strength, $5.8 \mathrm{MPa}$; and $q$ the overlying strata's load between the key strata and the immediate roof, $0.2925 \mathrm{MPa}$.

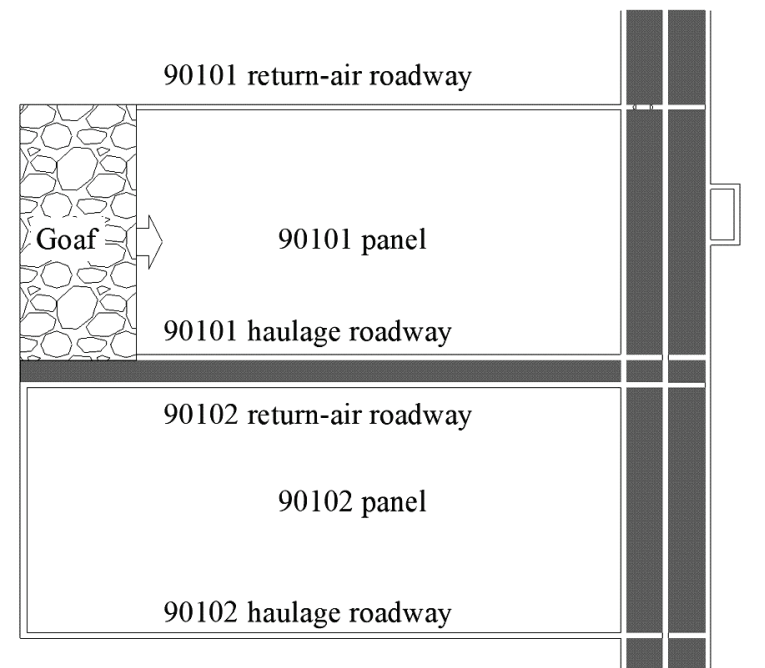

\begin{tabular}{|c|c|c|c|c|c|}
\hline $\begin{array}{c}\text { Stratigraphic } \\
\text { order }\end{array}$ & $\left\{\begin{array}{c}\text { Average } \\
\text { thickness } / \mathrm{m}\end{array}\right.$ & $\begin{array}{c}\text { Strata } \\
\text { position }\end{array}$ & Depth/m & Lithology & $\begin{array}{c}\text { Lithological } \\
\text { column }\end{array}$ \\
\hline 1 & 3.7 & & 152.6 & Limestone & \begin{tabular}{|llllll} 
& & & & & \\
& & & & \\
& & & & & \\
\end{tabular} \\
\hline 2 & 3.9 & & 156.5 & Mudstone & \begin{tabular}{|l}
------1 \\
------- \\
\end{tabular} \\
\hline 3 & 0.7 & $\begin{array}{c}7 \text { \#Coal } \\
\text { seam }\end{array}$ & 157.2 & Coal seam & \\
\hline 4 & 0.8 & & 158 & Mudstone & ------- \\
\hline 5 & 4.3 & Key strata & 162.3 & Siltstone & 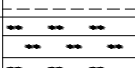 \\
\hline 6 & 2.6 & & 164.9 & Limestone & | \\
\hline 7 & 1.5 & & 166.4 & Mudstone & 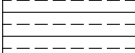 \\
\hline 8 & 1.6 & & 168 & Siltstone & 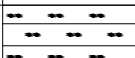 \\
\hline 9 & 2.9 & Main roof & 170.9 & $\begin{array}{c}\text { Fine } \\
\text { sandstone }\end{array}$ & 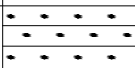 \\
\hline 10 & 3.1 & & 174 & Mudstone & \begin{tabular}{|l}
------- \\
-------- \\
\end{tabular} \\
\hline 11 & 3.0 & $\begin{array}{c}\text { Immediate } \\
\text { roof }\end{array}$ & 177 & Limestone & \begin{tabular}{|lllll|l|l|} 
& & & & \\
& & & & \\
& & & & & \\
\end{tabular} \\
\hline 12 & 3.0 & $\begin{array}{c}9+10 \# \\
\text { Coal seam }\end{array}$ & 180 & Coal seam & \\
\hline 13 & 1.9 & $\begin{array}{c}\text { Immediate } \\
\text { floor }\end{array}$ & 181.9 & Mudstone & \begin{tabular}{|l}
------- \\
--------
\end{tabular} \\
\hline 14 & 6.3 & Main floor & 188.2 & Siltstone & \begin{tabular}{|llll}
.. & &.. &.. \\
&.. &.. & \\
\end{tabular} \\
\hline
\end{tabular}

a) View of 90101 panel

b) Stratigraphic column

Figure 1 View of 90101 panel and stratigraphic column

Based on the physical and mechanical parameters of rock mass at the 90101 panel, the first roof weighting length is $L_{\mathrm{S}}=18.9 \mathrm{~m}$, and the periodic roof weighting length is $L=15.4 \mathrm{~m}$. It is likely to result in roadside support body instability and even wind blast damage. Therefore, some control measures must be carried out to prevent LARW accidents.

\section{AN INNOVATIVE APPROACH FOR GER WITH THR 3.1 LARW Analysis for GER with THR}

LARW is a dynamic phenomenon caused by roof movement with a large area roof breaking and caving. LARW happens in the thick and hard rock strata, including sandstone, limestone, conglomerate, granite and other stones which have the high tensile strength and compressive strength. The phenomenon of the LARW in GER can be divided into three stages, which are shown in Fig. 2.

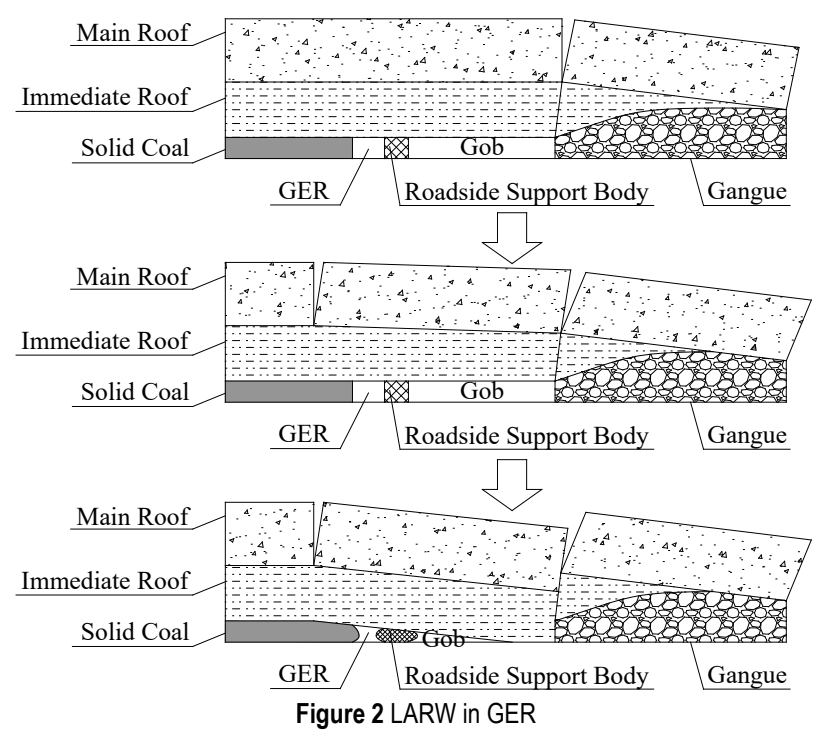

In the first stage, with the advance of the panel and the construction of the roadside support body, the suspended area of roof increases and the roof breaks near the gob.

In the second stage, the overlying roof bends and sinks and the main roof breaks secondly above the solid coal. Meanwhile, the roadside support body begins to bear and the main roof breaks secondly above the solid coal.

In the third stage, due to the overburden strata load, the overlying roof bends and sinks until the roof stress is greater than its tensile strength. Thence, the suspended roof will break and cave and LARW will possibly happen. During this stage, roadside support body and GER may be damaged and destroyed for rock bump and large deformation.

\subsection{The Rational of Shallow-Hole Blasting to Force Roof Caving for GER with THR \\ 3.2.1 Mechanism of shallow-hole blasting to Force Roof Caving for GER with THR}

After the detonation of the explosive in the immediate roof, the immediate roof strata are affected by dynamic actions from shock waves and high pressure gases. As a result, the damage of the immediate roof strata presents obvious zone characteristics. The roof strata can be divided into the crushing zone, the fracture zone and the fragment formation zone [19], as shown in Fig. 3. 


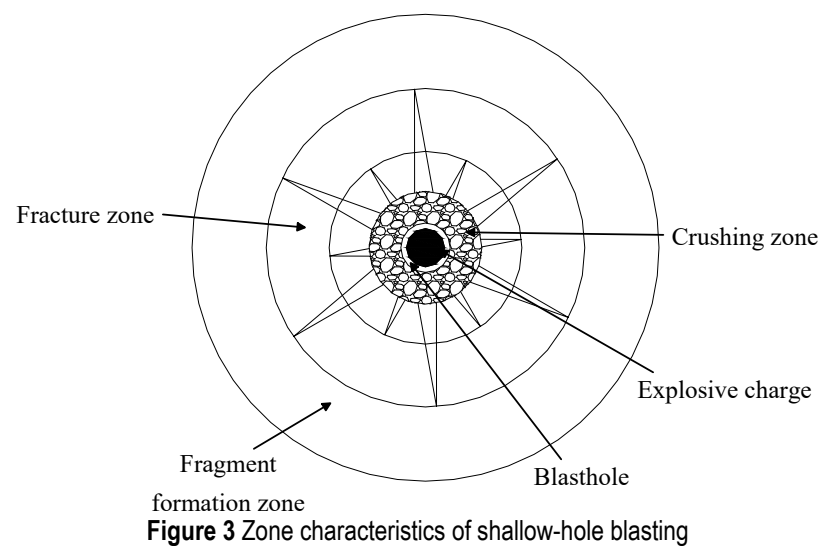

Research and experiments indicate that the radius of crushing zone is about 3-5 times the blasthole radius, and the fracture zone is around 10-15 times the blasthole radius. The radius of fracture zone can be obtained by the following equation $[20,21]$ :

$R_{\mathrm{f}}=\left[\frac{v \rho_{0} D_{\mathrm{c}}^{2}}{(1-v) 8 \sigma_{\mathrm{t}}}\right] \frac{1}{\left(2-\frac{v}{1-v}\right)} r_{0}$

where $\rho_{0}$ is the density of explosive, $\mathrm{kg} / \mathrm{m}^{3} ; D_{\mathrm{c}}$ is the velocity of explosive, $\mathrm{m} / \mathrm{s} ; r_{0}$ is the radius of the blasting hole, $\mathrm{m} ; v$ is the rock Poisson's ratio; $\sigma_{\mathrm{t}}$ is the roof stratum's tensile strength, MPa.

According to the space-time relationship of GER with THR, shallow-hole blasting technology can be used to cut off the immediate roof behind the hydraulic support. Meanwhile, the roadside support body will bears less roof pressure after the immediate roof caves, the main roof will form a hinge structure and protect the small structure of GER [22].

\subsubsection{Key parameters of shallow-hole blasting to Force Roof Caving for GER with THR}

According to the shallow-hole blasting technology and the demands of GER, the key parameters of shallowhole blasting to force roof caving mainly include the depth of the blasthole, the distance between the roadside support body and the blasthole, the space of the blasthole, the dip angle of the blasthole, and the cycle distance of blasthole, as shown in Fig. 4. The depth of the blasthole, the distance between the roadside support body and the blasthole and the space of the blasthole are related with the shallow-hole blasting crushing zone and fracture zone. The cycle distance of blasthole is relevant with the roof weighting length. These key parameters can be expressed by the following equations:

$$
\begin{aligned}
& l=\frac{k\left(h-R_{\mathrm{f}}\right)}{\sin \theta} \\
& d=k \cdot R_{\mathrm{f}} \\
& s=\frac{2 R_{\mathrm{f}}}{k} \\
& \Delta L=\frac{L}{k}
\end{aligned}
$$

where $l$ is the depth of the blasthole, $\mathrm{m} ; h$ is the immediate roof's thickness, $\mathrm{m} ; R_{\mathrm{f}}$ is the fracture zone radius, $\mathrm{m} ; \theta$ is the dip angle of the blasthole, i.e. roof caving angle, ${ }^{\circ} ; k$ is the safety factor; $d$ is the distance between the roadside support body and the blasthole, $\mathrm{m} ; s$ is the space of the blasthole, $\mathrm{m} ; \Delta L$ is the cycle distance of blasthole, $\mathrm{m}$.

\subsection{An innovative approach for GER with THR based on shallow-hole blasting technology}

From the above analysis, an innovative approach for GER with THR based on shallow-hole blasting technology was proposed, as illustrated in Fig. 4.

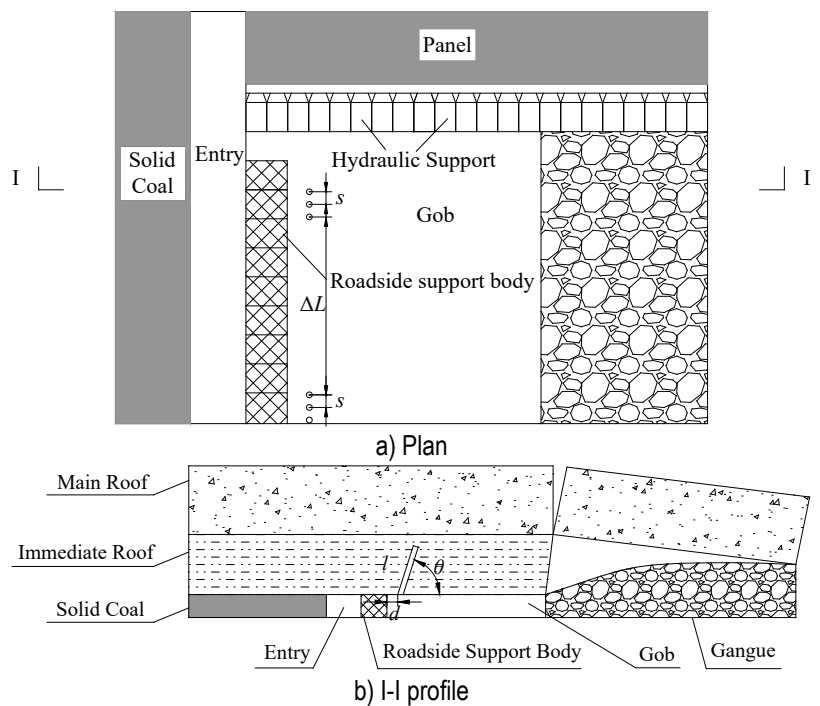

Figure 4 Key parameters of shallow-hole blasting to force roof caving

The air-return roadway of the panel serves the whole minig district as a tailgate for water drainage. After the panel 90101 is mined out, the gob water will flow from the greater contour (the haulage) to the lesser contour (the airreturn roadway). When mining the panel 90101, the roadside backfill body will be constructed by using the quick-setting materials with high water content behind the hydraulic face-end supports. When the length mined out is alomost the periodic roof weighting length, a row of blastholes (three shallow blastholes) will be drilled out of the roadside backfill body. Then, the immediate roof will cave as a result of shallow-hole blasting.

In this paper, one Chinese longwall panel involving GER application for gas drainage and the instrumentation data of gateroad deformation will be introduced. Numerical modeling techniques will then be used to validate the rational shallow-hole blasting parameters for GER and discuss the effect of shallow-hole blasting to force roof caving for GER.

\section{CASE STUDY \\ 4.1 Engineering Background}

The 90101 panel in Xinchao Colliery located north of the Qinshui coalfield in Shanxi Province of China was selected for the case study. The test of GER was carried out in the air-return roadway of 90101 panel. The cross-section of air-return roadway was $4.2 \mathrm{~m}$ wide and $3.0 \mathrm{~m}$ high, and 
the support parameters of GER including road-in support parameters and roadside support parameters are as follows.

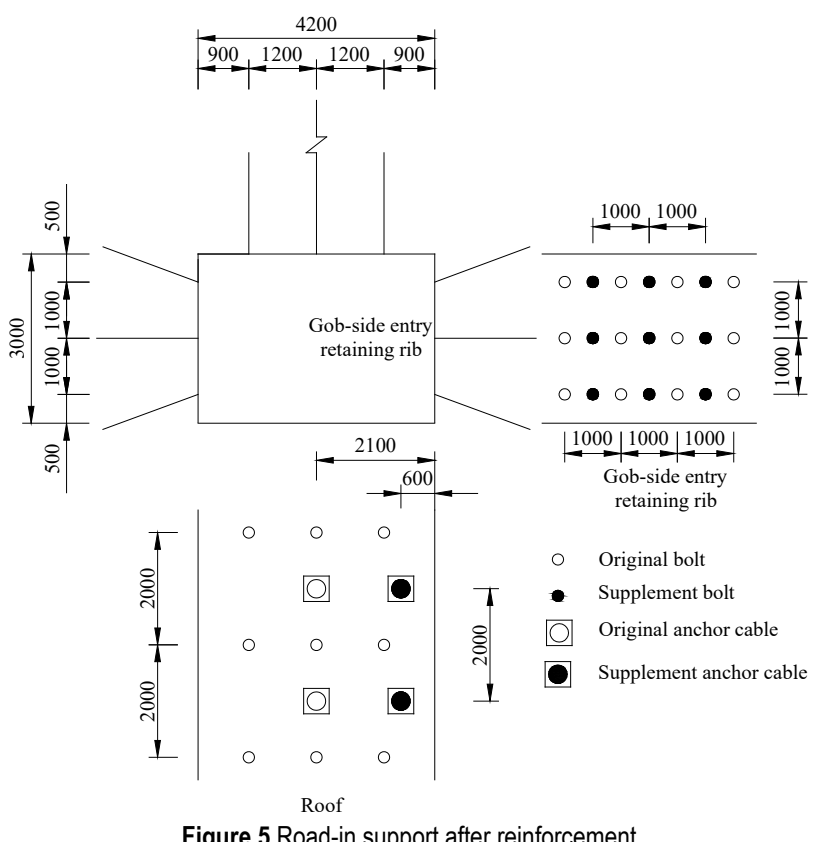

Figure 5 Road-in support after reinforcement

\subsubsection{Road-In Support}

The retained roadway will be used for drainage after mining. Support strength in the roadway was weak and could not ensure the effect of GER after 90101 return-air roadway dig without considering GER. Thence road-in support must be reinforced. Reinforcement program was proposed as follows: a row of supplement bolts was setting between two rows of original bolts; high-strength bolt with $20 \mathrm{~mm}$ in diameter and $2400 \mathrm{~mm}$ long was used in the GER rib reinforcement support; the supplement bolts of every row space at $1000 \mathrm{~mm}$, and the rows were to be spaced at $1000 \mathrm{~mm}$ along the length of the roadway. In order to enhance the supporting effect of roadside support, a row of supplement cable bolts with $17.8 \mathrm{~mm}$ in diameter and 6000 $\mathrm{mm}$ long were used in the roof support above roadside backfill body; the supplement cable rows were to be spaced at $1600 \mathrm{~mm}$ along the length of the roadway. Road-in support after reinforcement is shown in Fig. 5.

\subsubsection{Roadside Support}

According to the geological conditions and requirement of GER, the minimum width of GER was 3.0 $\mathrm{m}$, i.e. roadside support body located in the roadway partly and in the gob partly, of which the width was $3 \mathrm{~m}$ and the aspect ratio was 0.94 [23].

Table 1 Compressive strength of high water material different under water-cement ratios

\begin{tabular}{|c|c|c|c|c|c|c|c|}
\hline \multirow{2}{*}{$\begin{array}{c}\text { Water-cement } \\
\text { ratio }\end{array}$} & $\begin{array}{c}\text { Cementing dosage } \\
/ \mathrm{kg} / \mathrm{m}\end{array}$ & \multirow{2}{*}{ Water dosage $/ \mathrm{kg} / \mathrm{m}$} & \multirow{2}{*}{$\begin{array}{c}\text { Gellitation time } \\
/ \mathrm{min}\end{array}$} & \multicolumn{4}{|c|}{ Compressive strength $/ \mathrm{MPa}$} \\
\cline { 5 - 8 } & & & $24 \mathrm{~h}$ & $24 \mathrm{~h}$ & $7 \mathrm{~d}$ & $28 \mathrm{~d}$ \\
\hline 0.8 & 873 & 698 & 7 & 14.40 & 19.0 & 21.32 & 22.55 \\
\hline 1.0 & 744 & 744 & 8 & 10.2 & 15.8 & 17.90 & 19.10 \\
\hline 1.2 & 647 & 776 & 8 & 8.40 & 14.0 & 15.22 & 16.97 \\
\hline 1.5 & 542 & 813 & 10 & 4.48 & 9.14 & 10.36 & 11.51 \\
\hline 2.0 & 426 & 850 & 12 & 3.33 & 6.26 & 7.92 & 8.70 \\
\hline 2.25 & 385 & 866 & 14 & 2.42 & 4.74 & 6.19 & 7.08 \\
\hline 2.5 & 352 & 880 & 16 & 2.05 & 3.97 & 5.08 & 5.44 \\
\hline
\end{tabular}

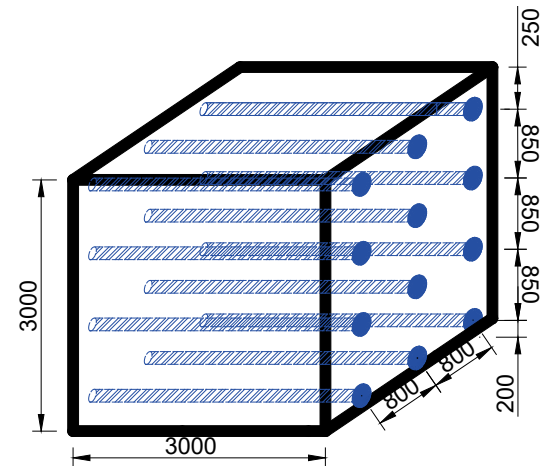

Figure 6 Three-dimensional roadside backfill body

At present, high water material is widely applied for roadside backfill in GER for its advantages including plentiful sources, low cost, high compressive strength. According to relevant experiment results and existing research results, high water material with water-cement ratio 1.5:1 was used to construct the roadside support body. Relationship between water-cement ratio of high water material and compressive strength is shown in Tab. 1 [24].

Counter-pulled bolts with $22 \mathrm{~mm}$ in diameter and 3200 $\mathrm{mm}$ long were used to increase the bearing capacity of backfill body and ability to resist lateral deformation. The counter-pulled bolts of every row space at $850 \mathrm{~mm}$ and the rows were to be spaced at $800 \mathrm{~mm}$ along the length of the roadway. Three-dimensional backfill body is shown in Fig. 6. The bottom counter-pulled bolt was $200 \mathrm{~mm}$ apart from the floor, and the top counter-pulled bolt was $250 \mathrm{~mm}$ apart from the roof. Meanwhile, steel ladder beam was welded with $14 \mathrm{~mm}$ round steel in diameter and $3000 \mathrm{~mm}$ long, as shown in Fig. 6.

Table 2 Key parameters of shallow-hole blasting to force roof caving

\begin{tabular}{|l|c|}
\hline \multicolumn{1}{|c|}{ Parameter type } & Value $/ \mathrm{m}$ \\
\hline Depth of the blasthole $(l)$ & 2.5 \\
\hline $\begin{array}{l}\text { Distance between the roadside support body and the } \\
\text { blasthole }(d)\end{array}$ & 0.9 \\
\hline Space of the blasthole $(s)$ & 1.5 \\
\hline Cycle distance of blasthole $(\Delta L)$ & 14 \\
\hline
\end{tabular}

\subsection{Design of Shallow-Hole Blasting to Force Roof Caving in GER}

On the basis of the laboratory results, the parameters employed in the model have been determined. Moreover, according to geological conditions of No. 90101 panel in Xinchao Colliery, relevant parameters can be obtained as follows: $\rho_{0}=1200 \mathrm{~kg} / \mathrm{m}^{3}, D_{\mathrm{c}}=3500 \mathrm{~m} / \mathrm{s}, \sigma_{\mathrm{c}}=136.6 \mathrm{MPa}$, $r_{0}=3.75 \times 10^{-2} \mathrm{~m}, v=0.3, \sigma_{\mathrm{t}}=5.8 \mathrm{MPa}, k=1.1, \theta=75^{\circ}$. Integrating the above data into Eqs. (3) to Eqs. (7), it can 
be calculated that the key parameters of shallow-hole blasting to force roof caving mainly are shown in Tab. 2 .

\subsection{Field Practice and Field Measurement}

According to the theoretical calculations and the numerical simulations above, to prevent the roadside support body and GER being damaged and destroyed for rock bump and large deformation during the stage of LARW, shallow-hole blasting technology to force roof caving was carried out at the 90101 panel in Xinchao Colliery.

Based on the above research, the blasting hole is laid out with $1.5 \mathrm{~m}$ space, $2.5 \mathrm{~m}$ depth and angle $75^{\circ}$ to the goaf direction. Meanwhile, the distance to the roadside backfill body is $1.0 \mathrm{~m}$ to prevent the roadside backfill body being destroyed. The specific parameters of the blasting hole are shown in Tab. 3. Layout of the blasting hole is shown in Fig. 7. The cycle distance of blasthole $(\Delta L)$ is $14 \mathrm{~m}$ to prevent LARW.

\begin{tabular}{|c|c|c|c|c|c|}
\hline \multirow{2}{*}{$\begin{array}{c}\text { Depth/ } \\
\text { m }\end{array}$} & \multirow{2}{*}{$\underset{/}{\text { Angle }}$} & \multirow{2}{*}{$\begin{array}{l}\text { Blasting } \\
\text { hole } \\
\text { diameter } \\
/ \mathrm{mm} \\
\end{array}$} & \multicolumn{2}{|c|}{$\begin{array}{c}\text { Explosive payload of a } \\
\text { single hole }\end{array}$} & \multirow{2}{*}{$\begin{array}{c}\text { Mudcap } \\
\text { length } \\
/ \mathrm{m}\end{array}$} \\
\hline & & & $\begin{array}{c}\text { cartridge } \\
\text { count }\end{array}$ & $\begin{array}{l}\text { Quality } \\
\text { /kg }\end{array}$ & \\
\hline 2.5 & 75 & 75 & 6 & 1.2 & 0.6 \\
\hline
\end{tabular}

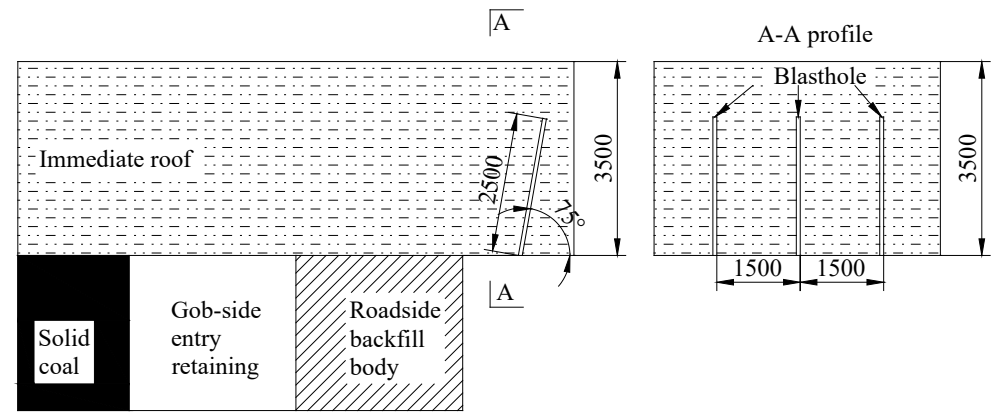

Figure 7 Layout of the blasting hole

\section{DISCUSSION}

\subsection{Numerical Simulation for Shallow-Hole Blasting 5.1.1 Numerical Model $[17,20]$ and Simulation Plans}

LS-DYNA is applied to simulate rock blasting, which is explicit dynamic analysis software. A numerical model for shallow-hole blasting is established based on ALE and fluid-structure interaction method. In order to analyze the blasting effect under different blasthole space, the monitoring point at the middle of the two blasthole center line is set by the difference of the effective stress (Von Misses stress). The geometry size of the numerical model is length $\times$ width $\times$ height $=3500 \times 2500 \times 2000 \mathrm{~mm}$ and the model is shown in Fig.8. In this model, the radius of blasting hole is $37.5 \mathrm{~mm}$ while the radius of explosive package is $25 \mathrm{~mm}$, and the depth of blasthole is $2500 \mathrm{~mm}$.

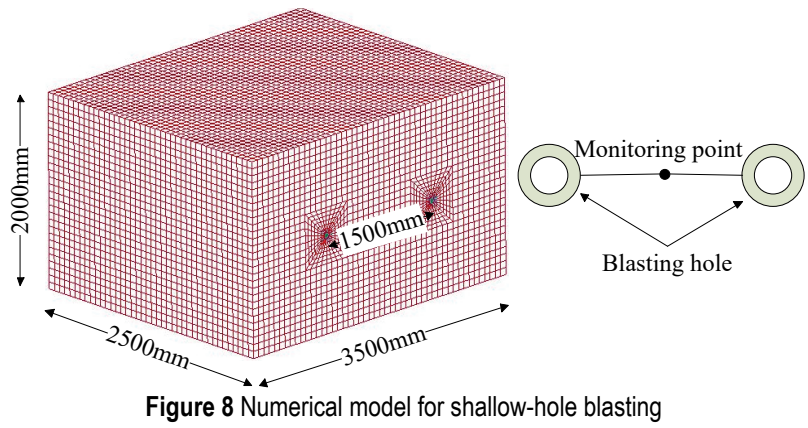

In order to illustrate the relationship between the pressure and the volume in the explosive detonating process, the Jones-Wilkens-Lee(JWL) state equation is applied to describe the relationship between the pressure and the volume of the explosive product, as shown in Eq. (9):

$$
P=A\left(1-\frac{\omega}{R_{1} V}\right) \mathrm{e}^{-R_{1} V}+B\left(1-\frac{\omega}{R_{2} V}\right) \mathrm{e}^{-R_{2} V}+\frac{\omega E_{0}}{V}
$$

where, $P$ is the detonation product unit pressure; $V$ is the detonation product relative volume; $E_{0}$ is the detonation product initial internal energy density; $A, B, R_{1}, R_{2}$ and $\omega$ are the material constants obtained by the experiments.

The parameters of the permissible emulsion explosive used in $2^{\text {nd }}$-class coal mines are shown in Tab. 4 together with the JWL state equation.

Table 4 Properties of explosive and JWL equations

\begin{tabular}{|c|c|c|c|c|c|c|c|}
\hline$\rho_{0} / \mathrm{kg} / \mathrm{m}^{3}$ & $D_{c} / \mathrm{m} / \mathrm{s}$ & $A / \mathrm{GPa}$ & $B / \mathrm{GPa}$ & $R_{1}$ & $R_{2}$ & $\omega$ & $E_{0} / \mathrm{GPa}$ \\
\hline 1200 & 3500 & 214.4 & 0.182 & 4.2 & 0.9 & 0.15 & 4.192 \\
\hline
\end{tabular}

The LS-DYNA3D uses kinematic hardening plastic model, which is relevant with the strain rate and considers the material failure effect. Mechanical parameters of rock in the model are shown in Tab. 5.

Table 5 Mechanical parameters of rock in the model

\begin{tabular}{|c|c|c|c|}
\hline$\rho_{\mathrm{m}} / \mathrm{kg} / \mathrm{m}^{3}$ & 2400 & Shear $/ \mathrm{GPa}$ & 10.5 \\
\hline Bulk $/ \mathrm{GPa}$ & 15 & $v$ & 0.3 \\
\hline Yielding stress $/ \mathrm{MPa}$ & 90 & Cohesion $/ \mathrm{MPa}$ & 6.72 \\
\hline Friction $/{ }^{\circ}$ & 42 & Dynamic tension $/ \mathrm{MPa}$ & 40 \\
\hline
\end{tabular}

In general, the numerical model is generated in the first step. In the second step, the two blasthole is developed. Then the blasting is carried out in the two blasthole with different blasthole space $(1.2 \mathrm{~m}, 1.5 \mathrm{~m}, 1.8 \mathrm{~m})$ in the third step. The theoretical calculation result indicates that the reasonable blasthole space is $1.5 \mathrm{~m}$. Hence, simulation of the proposed three different blasthole space may be helpful in the development of the shallow-hole blasting design for GER with THR. 


\subsubsection{Relationship between Effective Stress and Blasthole Space}

The effective stress of monitoring point for different blasthole space is obtained by importing the results from the LS-DYNA3D solver to the LS-PREPOST processor. The effective stress curves varying with the operating time are shown in Fig. 9.

Fig. 9 illustrates the relationship between blasthole space and the effective stress curves of monitoring point, which are described below.

(1) With the decrease of the blasthole space, the maximum effective stress of monitoring point increases. When the blasthole space is $1.2 \mathrm{~m}$, the maximum effective stress of monitoring point is $92.3 \mathrm{MPa}$; when the blasthole space is $1.5 \mathrm{~m}$, the maximum effective stress of monitoring point is $74.5 \mathrm{MPa}$; when the blasthole space is $1.8 \mathrm{~m}$, the maximum effective stress of monitoring point is $57.4 \mathrm{MPa}$.

(2) There are two peak stresses at the monitoring point along with time, but the second peak stress is less than the first. Meanwhile, both the first peak stress and the second peak stress decrease with the increase of the blasthole space. Above results are because of the superposition of stress wave after the blasting.

(3) The effective stress of monitoring point tends to stable finally and the stable maximum effective stress of monitoring point has a negative correlation with the blasthole space. When the blasthole space is $1.2 \mathrm{~m}$, the stable effective stress of monitoring point is about $60 \mathrm{MPa}$; when the blasthole space is $1.5 \mathrm{~m}$, the stable effective stress of monitoring point is about $40 \mathrm{MPa}$; when the blasthole space is $1.8 \mathrm{~m}$, the stable effective stress of monitoring point is about $20-30 \mathrm{MPa}$.

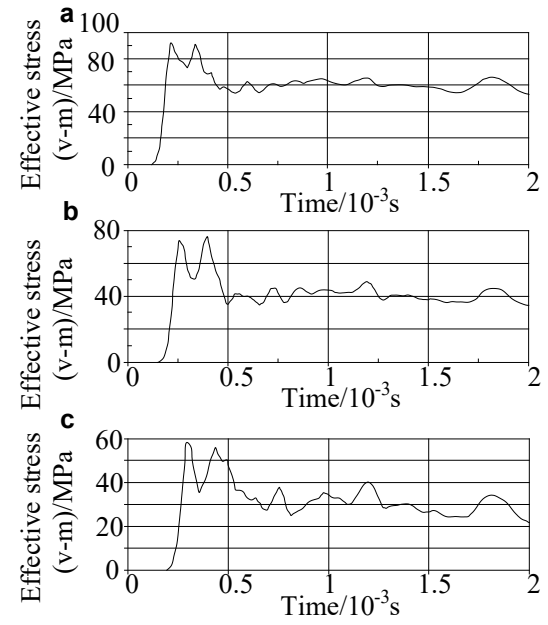

Figure 9 The effective stress curves of monitoring point for different blasthole space: (a) space $1.2 \mathrm{~m}$ (b) space $1.5 \mathrm{~m}$ (c) space $1.8 \mathrm{~m}$

(4) According to rock blasting tensile failure criteria, rock will be damaged and broken when the effective stress is more than the rock dynamic tension. When the blasthole space is $1.2 \mathrm{~m}$ or $1.5 \mathrm{~m}$, the stable effective stress of monitoring point will be more than the rock dynamic tension; conversely, when the blasthole space is $1.8 \mathrm{~m}$, the stable effective stress of monitoring point is less than the rock dynamic tension. Based on the relationship between the stable effective stress of monitoring point and the blasthole space, the reasonable blasthole space is $1.5 \mathrm{~m}$.

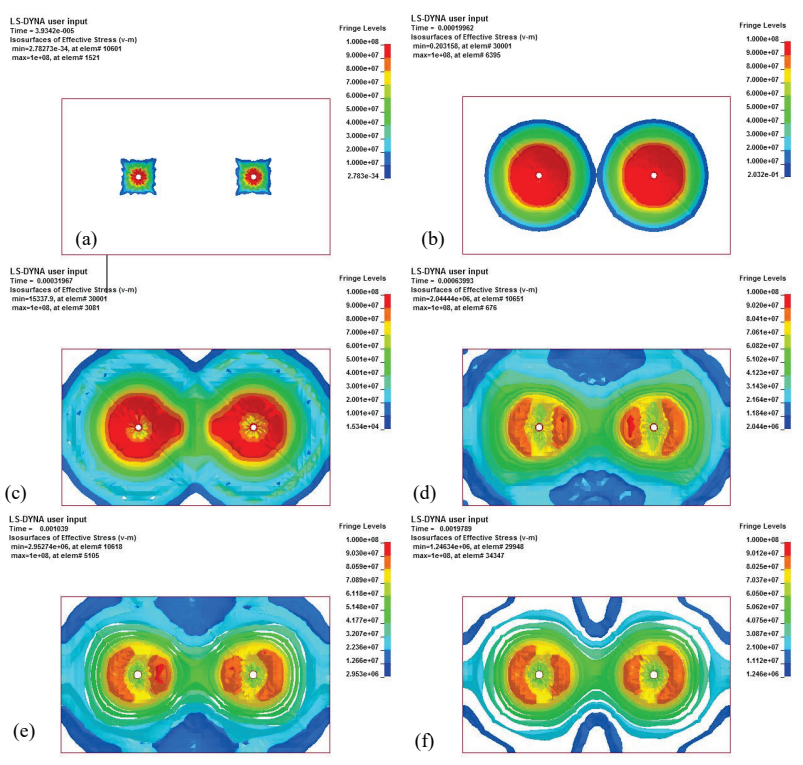

Figure 10 Effective stress evolvement for shallow-hole blasting (in the front view): (a) $39.342 \mu \mathrm{s}$, (b) $199.62 \mu \mathrm{s}$, (c) $319.67 \mu \mathrm{s}$, (d) $639.93 \mu \mathrm{s}$, (e) $1039 \mu \mathrm{s}$, (f) $1959 \mu \mathrm{s}$

\subsubsection{Effective Stress Evolvement for Shallow-Hole Blasting}

Taking the determined blasthole space of $1.5 \mathrm{~m}$ for shallow-hole blasting scheme as a case, the effective stress evolvement is shown in Fig. 10 (in the front view). When blasting time is to $39.342 \mu \mathrm{s}$, the effect radius of explosion stress wave is $136 \mathrm{~mm}$; when blasting time is to $199.62 \mu \mathrm{s}$, the effect radius of explosion stress wave is $577 \mathrm{~mm}$, and this range is out of the crushing zone radius; when blasting time is to $319.67 \mu \mathrm{s}$, the effect radius of explosion stress wave is $735 \mathrm{~mm}$; when blasting time is to $639.93 \mu \mathrm{s}$, the effect radius of explosion stress wave is greater than 900 $\mathrm{mm}$, and this range is out of the space of blastholes.

\subsection{Numerical Simulation for Shallow-Hole Blasting to Force Roof Caving by Discrete Element}

To validate the shallow-hole blasting to force roof caving effect, the discrete element program UDEC has been used to establish and analyze the model. The model dimension is length $\times$ height $=160 \times 51.4 \mathrm{~m}$. To eliminate the boundary effect, a length of $50 \mathrm{~m}$ coal pillar has been left at the right border, and the designed excavation length of the panel is $100 \mathrm{~m}$. The two side boundaries of the model are applied with horizontal displacement restraint, and the bottom boundary is applied with the vertical displacement restraint. The constitutive equation adopted in this model is Mohr-Coulomb criterion. The mechanical properties of the surrounding rock are determined by the field geological conditions and the laboratory tests.

To simulate the effect of shallow-hole blasting in the model, the depth of the blasthole is $2.5 \mathrm{~m}$, the distance between the roadside support body and the blasthole is 1.0 $\mathrm{m}$, and the dip angle of the blasthole is $75^{\circ}$. According to the crushing zone of shallow-hole blasting, the blasting zone diameter is $0.3 \mathrm{~m}$.

Fig. 11 shows the overlying strata movement results after the GER is finished. When the simulation ends, the immediate roof does not cave and rotates towards the goaf in the no blasting model (Fig. 11a). The roadside support body is in an unstable state because of LARW. The roof to 
floor convergence and rib to rib convergence are respectively $365 \mathrm{~mm}$ and $836 \mathrm{~mm}$, especially the roadside support body convergence is $682 \mathrm{~mm}$ with the crossing method. After the measure to force roof caving undertaken, the immediate roof breaks along the blasting zone (Fig. $11 b)$. The roadside support body is in a stable state, and the roof to floor convergence and rib to rib convergence are

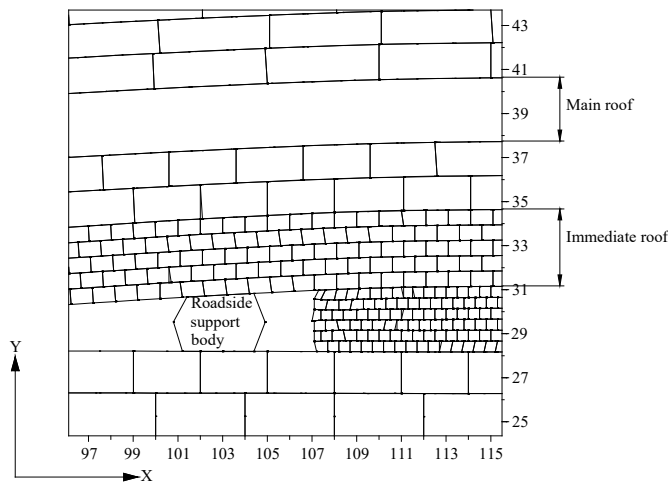

a)

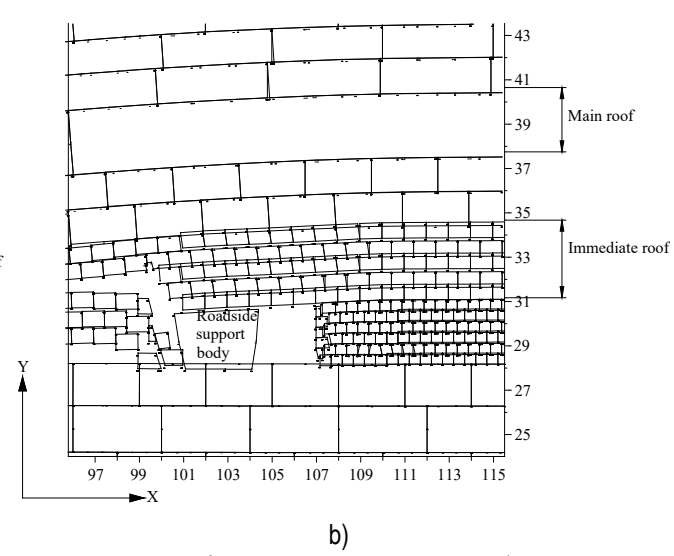

b)

Figure 11 Numerical simulation result of the overlying strata movement: a) Numerical simulation result of the model without blasting, b) Numerical simulation result of the model with blasting

\subsection{Effect Analysis for GER}

In order to study the performanceof GER in its life, observation results of closure condition of GER were recorded during the panel mining period, as shown in Fig. 12. When the panel passed an observation site at a distance of $75 \mathrm{~m}$, the roadway convergence was almost unchanged. The maximum roof to floor convergence and rib convergence were respectively $357 \mathrm{~mm}$ and $292 \mathrm{~mm}$ behind the panel 90101. Effect for GER is shown in Fig. 13. Roof caving after shallow-hole blasting is shown in Fig. 14.

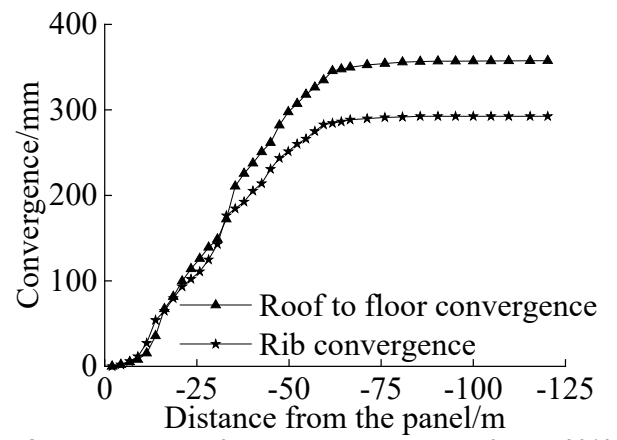

Figure 12 Closure condition of gob-side entry retaining of panel 90101 during the panel-mining period

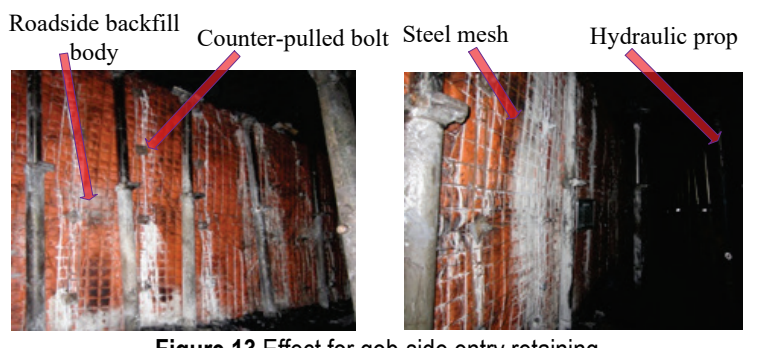

Figure 13 Effect for gob-side entry retaining

Considering the requirement of roadway crosssections for drainage, the section of GER in the panel mining period could meet the requirement. Field respectively $303 \mathrm{~mm}$ and $284 \mathrm{~mm}$, especially the roadside support body convergence is $198.5 \mathrm{~mm}$. Thus, the UDEC simulation results indicate that the convergence of the GER can decrease and the roadside support body can be stable after the application of the shallow-hole blasting technology to force roof caving.

measurement results indicated that technology for ground control in GER was rational, and confirmed the feasibility of the new technology for roof control in GER.

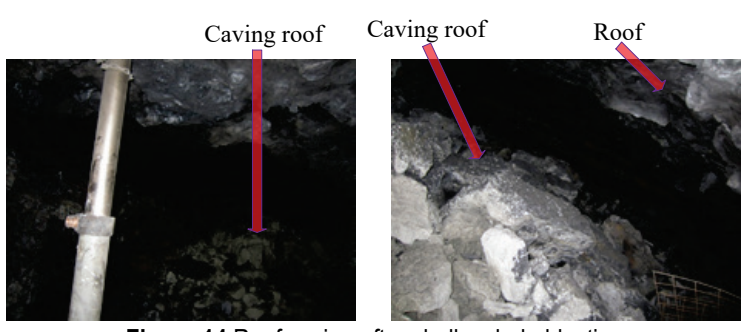

Figure 14 Roof caving after shallow-hole blasting

\section{CONCLUSION}

Some roadways for gob water drainage in the coal mines, which were mined chaotically in the past decades in China, are difficult to retain the roadway with THR. Thus, an innovative approach for GER with THR based on shallow-hole blasting technology is proposed for gob water drainage.

To avoid LARW and other dynamic disasters in GER with THR, numerical simulations including the effective stress evolution law for different blasthole space researched by LS-DYNA3D and the shallow-hole blasting to force roof caving effect validated by UDEC were carried out respectively. The results indicate that when the blasthole space is $1.5 \mathrm{~m}$ and the blasthole depth is $2.5 \mathrm{~m}$, the stable effective stress of monitoring point is about 40 $\mathrm{MPa}$, and the immediate roof caves according to rock blasting tensile failure criteria. Theoretical calculation and numerical simulation results for the shallow-hole blasting for GER with THR provide a reasonable basis.

Field observation shows that GER based on the shallow-hole blasting technology with $1.5 \mathrm{~m}$ blasthole space and $2.5 \mathrm{~m}$ blasthole depth, designed road-in support scheme and roadside backfill body with a width of $3.0 \mathrm{~m}$ could meet the requirement. Immediate roof break and 
cave after those designed schemes are put into effect, ensuring the panel safe production. It also proves that the new roof control measures meet the requirement for GER with THR, and provide a new way to the GER in similar conditions.

\section{Acknowledgements}

This work is supported by National Natural Science Foundation of China (No. 51804111, No. 51574227, and No. 51504246), and the Scientific Research Fund of Hunan Provincial Education Department (No. 15B088 and 2018JJ3185).

\section{REFERENCES}

[1] Zhang, N., Yuan, L., Han, C. L., Xue, J. H., \& Kan, J. G. (2012). Stability and deformation of surrounding rock in pillarless gob-side entry retaining. Safety Science, 50, 593599. https://doi.org/10.1016/j.ssci.2011.09.010

[2] Tan, Y. L., Yu, F. H., Ning, J. G., \& Zhao, T. B. (2015) Design and construction of entry retaining wall along a gob side under hard roof stratum. International Journal of Rock Mechanics and Mining Sciences, 77, 115-121. https://doi.org/10.1016/j.jijmms.2015.03.025

[3] Hua, X. Z. (2006). Development status and improved proposals on gob-side entry retaining support technology in China. Coal Science and Technology, 34, 78-81.

[4] Deng, Y. H., Tang, J. X., Zhu, X. K., Fu, Y., \& Hu, H. (2011). Industrial test of concrete packing for gob-side entry retained in gently-inclined medium-thickness coal seam. Journal of Southwest Jiaotong University, 46, 523-528.

[5] Xie, W. B., Da J. Y., \& Feng, G. M. (2004). Mechanism of controlling surrounding rock around gob-side entry retaining in top-coal caving mining face. Journal of Central South University, 35, 657-661.

[6] Ma, L. Q., Zhang, D. S., Chen, T., \& Fan, G. W. (2007). Study on packing body supporting resistance of enter-in packing for in-situ gob-side entry retaining in fullymechanized top-coal caving mining face. Chinese Journal of Rock Mechanics and Engineering, 26, 544-550.

[7] Zhang, Z. Z., Bai, J. B., Chen, Y., \& Yan, S. (2015). An innovative approach for gob-side entry retaining in highly gassy fully-mechanized longwall top-coal caving. International Journal of Rock Mechanics and Mining Sciences, 80, 1-11. https://doi.org/10.1016/j.jjmms.2015.09.001

[8] Kang, H. P., Niu, D. L., Zhang, Z., Lin, J., Li, Z. H., \& Fan, M. J. (2010). Deformation characteristics of surrounding rock and supporting technology of gob-side entry retaining in deep coal mine. Chinese Journal of Rock Mechanics and Engineering, 29, 1977-1987.

[9] Bai, J. B., Zhou, H. Q., Hou, C. J., Tu, X. Z., \& Yue, D. Z. (2004). Development of support technology beside roadway in goaf-side entry retaining for next sublevel. Journal of China University of Mining and Technology, 33, 183-186.

[10] Tang, J. X., Hu, H., Tu, X. D., \& Deng, Y. H. (2010). Experimental on roadside packing gob-side entry retaining for ordinary concrete. Journal of China Coal Society, 35, 1425-1429.

[11] Huang, Y. L., Zhang, J. X., Zhang, Q., \& Zan, D. F. (2011) Technology of gob-side entry retaining on its original position in fully-mechanized coalface with solid material backfilling. Journal of China Coal Society, 36, 624-1628.

[12] Wang, M. S., Wang, M., \& Du, H. L. (2013). Gateway retained technology along goaf of coalmining face with thick and hard roof. Coal Science and Technology, 41, 42-45.
[13] Ning, J. G., Ma, P. F., Liu, X. S., Zhao, J., \& Liu, W. (2013). Supporting mechanism of yielding-supporting beside roadway maintained along the goaf under hard rocks. Journal of Mining and Safety Engineering, 30, 369-374.

[14] Hao, F. K., Zhou, T. X., \& Jiang, Y. C. (2006). Forced roof caving technology and application to goaf-side entry retaining. Coal Science and Technology, 34, 16-18+24.

[15] Gao, K., Liu, Z. G., Liu, J., Deng, D., Gao, X. Y., Kang Y., \& Huang, K. F. (2013). Application of deep borehole blasting to gob-side entry retaining forced roof caving in hard and compound roof deep well. Chinese Journal of Rock Mechanics and Engineering, 32, 1588-1594.

[16] Huang, B. X., Liu, C. Y., Fu, J. H., Hui, G. (2011). Hydraulic fracturing after water pressure control blasting for increased fracturing. International Journal of Rock Mechanics and Mining Sciences, 48, 976-983. https://doi.org/10.1016/j.jijmms.2011.06.004

[17] Wang, F. T., Tu, S. H., Yuan, Y., Feng, Y. F., Chen F., \& Tu, H. S. (2013). Deep-hole pre-split blasting mechanism and its application for controlled roof caving in shallow depth seams. International Journal of Rock Mechanics and Mining Sciences, 64, 112-121. https://doi.org/10.1016/j.ijrmms.2013.08.026

[18] Qian, M. G. \& Shi, P. W. (2003). Mining pressure and strata control. China University of Mining and Technology Press, Xuzhou.

[19] Zhang, Z. C. (1994). Basic theory and design construction technology for blasting. Chongqing University Press, Chongqing.

[20] Ma, G. W. \& An, X. M. (2008). Numerical simulation of blasting-induced rock fractures. International Journal of Rock Mechanics and Mining Sciences, 45, 966-975. https://doi.org/10.1016/j.jijmms.2007.12.002

[21] Liu, W. B., Yang, J. H., Chen, M., \& Zhou, C. B. (2011). An equivalent method for blasting vibration simulation. Simulation Modelling Practice and Theory, 19, 2050-2062. https://doi.org/10.1016/j.simpat.2011.05.012

[22] Zhang, Z. Z., Bai, J. B., Chen, Y., \& Hao, S. P. (2016). Shallow-hole blasting mechanism and its application for gob-side entry retaining with thick and hard roof. Chinese Journal of Rock Mechanics and Engineering, 35(S1), 30083017.

[23] Guo, T. Y., Zhang, Z. Z., Feng, P. H., \& Yuan, X. J. (2014). Gob-side entry retaining technology for working face with thick coal seam and hard roof. Coal Min Saf, 45(9), 72-74.

[24] Cheng, J., Li, W. F., \& Zhang, P. (2015). A novel backfill material for roof supports in the cut-through entries of longwall mining. Technical Gazette, 22(1), 201-208. https://doi.org/10.17559/TV-20141130115523

\section{Contact information:}

\section{Zizheng ZHANG}

(Corresponding author)

Work Safety Key Lab on Prevention and Control of Gas and Roof Disasters for Southern Goal Mines, Hunan Provincial Key Laboratory of Safe Mining Techniques of Coal Mines, Hunan University of Science and Technology, No. 1, Taoyuan Road, Yuhu District, Xiangtan 411201, Hunan Province, China E-mail: zhang-zi-zheng@163.com, hnustzzz@hnust.edu.cn

\section{Weijun WANG}

School of Resources, Environment and Safety Engineering, Hunan Provincial Key Laboratory of Safe Mining Techniques of Coal Mines, Hunan University of Science and Technology,

No. 1, Taoyuan Road, Yuhu District, Xiangtan 411201, Hunan Province, China E-mail: wjwang@hnust.edu.cn

\section{Shuqing LI}

Work Safety Key Lab on Prevention and Control of Gas and Roof Disasters for Southern Goal Mines, Hunan Provincial Key Laboratory of Safe Mining Techniques of Coal Mines, Hunan University of Science and Technology, 
No. 1, Taoyuan Road, Yuhu District, Xiangtan 411201, Hunan Province, China E-mail: Isq_hnust@163.com

\section{Jianbiao BAl}

State Key Laboratory of Coal Resources and Safe Mining,

China University of Mining and Technology,

No. 1, Daxue Road, Xuzhou, Jiangsu, 221116, China

E-mail: bjianb@163.com

\section{Shengpeng HAO}

State Key Laboratory of Coal Resources and Safe Mining,

China University of Mining and Technology,

No. 1, Daxue Road, Xuzhou, Jiangsu, 221116, China

E-mail: 1095785259@qq.com

\section{Hai WU}

Work Safety Key Lab on Prevention and Control of Gas and Roof Disasters for Southern Goal Mines, Hunan Provincial Key Laboratory of Safe Mining

Techniques of Coal Mines, Hunan University of Science and Technology,

No. 1, Taoyuan Road, Yuhu District, Xiangtan 411201, Hunan Province, China E-mail:23614995@ qq.com

\section{Xianyang YU}

Work Safety Key Lab on Prevention and Control of Gas and Roof Disasters for

Southern Goal Mines, Hunan Provincial Key Laboratory of Safe Mining

Techniques of Coal Mines, Hunan University of Science and Technology,

No. 1, Taoyuan Road, Yuhu District, Xiangtan 411201, Hunan Province, China

E-mail:363093669@qq.com 